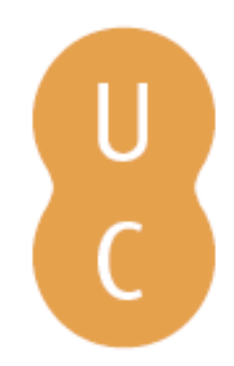

\title{
pompalina
}

\section{Flávio Josefo e o cerco romano a Jotapata (67 d.C.)}

\author{
Autor(es): $\quad$ Monteiro, João Gouveia
}

Publicado por: Imprensa da Universidade de Coimbra

URL

persistente: URI:http://hdl.handle.net/10316.2/34759

DOI: $\quad$ DOI:http://dx.doi.org/10.14195/978-989-26-0626-2_9

Accessed : $\quad$ 26-Apr-2023 15:18:18

A navegação consulta e descarregamento dos títulos inseridos nas Bibliotecas Digitais UC Digitalis, UC Pombalina e UC Impactum, pressupõem a aceitação plena e sem reservas dos Termos e Condições de Uso destas Bibliotecas Digitais, disponíveis em https://digitalis.uc.pt/pt-pt/termos.

Conforme exposto nos referidos Termos e Condições de Uso, o descarregamento de títulos de acesso restrito requer uma licença válida de autorização devendo o utilizador aceder ao(s) documento(s) a partir de um endereço de IP da instituição detentora da supramencionada licença.

Ao utilizador é apenas permitido o descarregamento para uso pessoal, pelo que o emprego do(s) título(s) descarregado(s) para outro fim, designadamente comercial, carece de autorização do respetivo autor ou editor da obra.

Na medida em que todas as obras da UC Digitalis se encontram protegidas pelo Código do Direito de Autor e Direitos Conexos e demais legislação aplicável, toda a cópia, parcial ou total, deste documento, nos casos em que é legalmente admitida, deverá conter ou fazer-se acompanhar por este aviso.

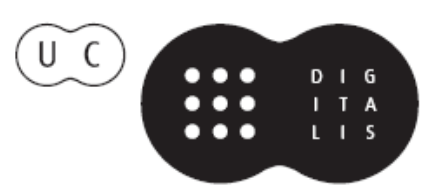




\title{
Saberes e poderes no Mundo Antigo
}

Estudos ibero-latino-americanos

\author{
Volume II - Dos poderes
}

Fábio Cerqueira, Ana Teresa Gonçalves, Edalaura Medeiros \& Delfim Leão (Orgs.)

IMPRENSA DA UNIVERSIDADE DE COIMBRA

UNIVERSIDADE FEDERAL DE PELOTAS

UNIVERSIDADE FEDERAL DE GOIÃS 


\title{
FLÁVIO JOSEFO E O CERCO ROMANO A JOTAPATA (67 d.C.)
}

\author{
João Gouveia Monteiro \\ Universidade de Coimbra - Portugal
}

\section{O contexto histórico-geográfico}

Quando Flávio Josefo nasceu, em 37 ou 38 d.C., a região da Síria-Palestina estava longe de ser um território homogéneo e pacificado. Para o compreendermos melhor, convém que recuemos dois séculos e meio ${ }^{1}$.

Em 200 a.C., na sequência da batalha de Panion, o rei selêucida Antíoco III conseguiu tornar-se senhor da Palestina, da cidade de Jerusalém e do seu precioso Templo. Trinta anos mais tarde, Antíoco IV Epifânio continuaria a luta contra os Ptolomeus do Egipto pela posse da totalidade do território sírio.

Com a chegada dos selêucidas à Terra Santa, a Judeia mudou, em especial porque o modelo grego começou a impor-se nas camadas superiores das regiões conquistadas e se incrementou o desenvolvimento urbano. A Judeia conheceu então um doloroso processo de aculturação, como prova o facto de os judeus que conhecemos terem passado a ter dois nomes próprios: um hebraico e outro grego. A ocupação selêucida gerou anti-corpos que nos ajudam a compreender a Revolta dos Macabeus (liderados por Judas), ocorrida em 168 a.C. e que acabou por estar na origem da formação do Estado judaico. O ano de 143-142 a.C. (o primeiro da era dos asmoneus) marca simbolicamente o nascimento do Estado judaico independente.

Cerca de três quartos de século mais tarde deu-se a anexação da Síria pelos romanos. Em 66-64 a.C., Pompeu Magno, depois de derrotar Mitridates (rei do Ponto), ocupou o território sírio eliminando as últimas reminiscências da monarquia selêucida. O pretexto para a intervenção militar de Pompeu foi uma guerra civil que estalara no seio do reino asmoneu de Jerusalém (entre os filhos de Alexandre Janeu e de Salomé: Hircano II e Aristobulo II). Ao fim de três meses de cerco, o general romano (a quem os irmãos desavindos haviam apelado) conseguiu capturar a Cidade Santa, tendo a maior parte dos combates travados durante esta operação tido lugar em redor ou no próprio grande Templo!

Quando se tornaram senhores de Jerusalém, os romanos começaram por manter o Asmomeu Hircano II (67-63 a.C.) na condição de Sumo-sacerdote. Contudo, na sequência das guerras civis que brotaram em Roma, os partos da

\footnotetext{
* Faculdade de Letras da Universidade de Coimbra. Centro de História da Sociedade e da Cultura (Universidade de Coimbra). Rua do Tirado 125, 3040-806 Coimbra. E-mail: jgmonteiro@mail.telepac.pt. Tel.: 239-947-538 // 96.55.83.320.
} 
Flávio Josefo e o cerco romano a Jotapata (67 d.C)

Mesopotâmia, em 40 a.C., invadiram o país a que os romanos chamaram Palestina e instalaram o príncipe asmoneu Antígono em Jerusalém, como seu cliente. Três anos mais tarde, porém, com o apoio de Marco António e do Senado romano, um idumeu de nome Herodes (antigo tetrarca da Galileia, filho do prefeito assassinado da Judeia, Antípater, um ex-apoiante de Júlio César) tornouse rei de Jerusalém, após um cerco de quatro meses à Cidade Santa que redundou num massacre horrível. Antígono seria executado e Herodes (um Edomita, da raça de Esaú) contando com o beneplácito romano e até com algum apoio asmoneu (pois casara habilmente com uma princesa asmoneia, Mariana), viria a reinar como monarca dos judeus da Palestina até 4 a.C., controlando um território mais extenso do que o próprio reino de David. Com ele, político astuto, Jerusalém tornou-se numa das mais importantes metrópoles do Oriente e também numa cidade solidamente protegida: a célebre fortaleza Antónia; o palácio de Herodes, com as suas três torres gémeas; etc. (Armstrong, 2002, p.125-127).

Poucos anos após a morte de Herodes (que não preparara devidamente a sua sucessão, o que fomentou uma tremenda agitação social ${ }^{2}$ ), o primeiro imperador romano, Octávio Augusto (27 a.C. - 14 d.C.), a quem Herodes erigira aliás um templo em Samaria, constituiria a província romana da Judeia, ainda que tal não tivesse representado exactamente o fim da presença monárquica diluída sob a forma de tetrarquias ou de micro-reinos. Para além da submissão da Judeia (dividida e confiada a prefeitos) e da Galileia (mais a norte), Augusto desenvolveu importantes acções diplomáticas junto dos partos. O seu sucessor, Tibério (14-37 d.C.), anexaria ainda os Estados de Filipe (a leste da Galileia). Acentuava-se, deste modo, a presença romana na Terra Santa, embora com a preocupação comum de evitar ofender a sensibilidade religiosa dos crentes e de cooperar com os Sumosacerdotes mais sensatos e diplomatas, como Caifás (18 d.C.). Daí o célebre episódio recordado por Vidal-Naquet (1977, p.86): à pergunta “Crucificarei o vosso rei?" feita, segundo João, pelo procurador Pôncio Pilatos aos judeus, responderam os Sumo-sacerdotes: "Nós não temos outro rei a não ser César"...

A presença romana apresentava, todavia, muitas fragilidades, agravadas por certas provocações de Pilatos em Jerusalém e Cesareia (em 26 d.C.) e pelo grande abalo causado, quatro anos depois, pelo aparecimento da figura de Jesus, cujo comportamento religioso e social inclusivo tinha implicações apocalípticas que o próprio Caifás não podia aceitar (o que levou à crucificação de Jesus, da qual resultaria contudo um movimento renovador ainda mais fecundo, como bem documenta a história dos seus principais seguidores, em especial a de Paulo de Tarso). Outro sinal de instabilidade é dado pela veemente resistência judaica à intenção do imperador Calígula de colocar uma sua estátua no santuário de Jerusalém (41 d.C.). Compreende-se, pois, que o seu sucessor, Cláudio, aspirando 
apaziguar os Judeus, tenha nomeado como rei da Palestina judaica o neto de Herodes, Agripa I (40-44 d.C.).

A morte prematura do bem sucedido Agripa I obrigou - sendo Agripa II ainda demasiado novo para reinar - a uma interessante solução de continuidade: Cláudio (41-54 d.C.) enviou um novo governador romano para a Judeia, mas apenas com o título de procurador, enquanto o jovem Agripa II conservou uma posição destacada no governo. Apesar do surgimento de profetas que prometiam a expulsão dos romanos (ao tempo dos procuradores Cumano e Félix), acabou por se estabelecer um modus vivendi entre a Judeia e Roma: em 59 d.C., o rei Agripa II recebeu autorização para fixar residência no antigo palácio dos Asmoneus, enquanto o procurador romano ocupava o de Herodes sempre que visitava Jerusalém. O Templo foi finalmente acabado e a cidade gozou de alguma autonomia, sendo governada conjuntamente por Agripa II e pelo Sumo-sacerdote, que cooperavam de forma positiva com o procurador romano em Cesareia (Armstrong, 2002, p.146).

No séc. I d.C., a Judeia era, assim, um território de grande complexidade, o interior contrastando com as cidades gregas ou helenizadas da região costeira. À Judeia propriamente dita e à Idumeia (mais a sul) acrescentava-se, a norte, a Samaria, um verdadeiro lugar de passagem para quem circulava de Jerusalém para a Galileia. Segundo Josefo, nos anos após o estabelecimento da província romana da Judeia os samaritanos mostraram-se súbditos rebeldes e inimigos característicos dos judeus. Em Samaria, tal como na Judeia, eclodiram movimentos de tipo messiânico no final da missão do procurador Pôncio Pilatos (26-36 d.C.).

Se Cesareia era, prudentemente, a capital política, Jerusalém era a capital religiosa e a maior cidade da Judeia. No entanto, só o olhar simplificador da chancelaria romana a poderia considerar uma polis grega. A cidade, praça-forte e sede do Templo, além de mercado, era profundamente heterogénea: a cidade alta estava muito helenizada, mas a cidade baixa (e não só) permanecia classicamente oriental. Esta diversidade palestiniana e judaica é confirmada por Flávio Josefo, que numa célebre descrição inserta em $A$ Guerra dos Judeus (J. BJ 3.3.35-47) ( $^{3}$ opõe a alta Galileia (nos flancos do Líbano) à baixa Galileia (mais profundamente helenizada, o lugar do ensinamento de Jesus).

Parece também claro que, no seio dos movimentos revolucionários de que nos dá conta Josefo, conviveriam messianismo e ruralidade. A um messianismo revolucionário e dinástico acrescentavam-se, quer uma prática social 'terrorista' (cf. o movimento dos sicários), quer a fundação e o desenvolvimento de novas seitas político-religiosas. Compreende-se o espanto de autores como Tácito perante o fenómeno do messianismo judaico. 
Flávio Josefo e o cerco romano a Jotapata (67 d.C)

Quando rebenta a revolta de 66 d.C. continua a haver um rei judeu, moderado e conciliador: Agripa II, cujo território se estende ao Nordeste da Judeia. É muito instrutivo o discurso de advertência aos judeus colocado por Josefo na boca de Agripa II, por ocasião da deflagração da revolta: "Não existe no mundo inteiro um único povo no seio do qual não se encontre uma fracção da nossa raça. Se vós fazeis a guerra, os inimigos deles degolá-los-ão a todos e, por causa da decisão fatal de uns poucos, não existirá uma cidade que não fique saciada de sangue judaico" (J. BJ 2.16.399). Este discurso terá, claro, de ser perspectivado levando em linha de conta as esperanças de Josefo na monarquia romana. Como escreve Vidal-Naquet (1977, p.93-94), o escritor "esforça-se por desviar em direç̧ão ao imperador romano, único monarca 'frio' que poderia governar o país judaico, a corrente que se dirigia, se não para a conquista do mundo, pelo menos para a subversão de que Judas e os seus são para ele os símbolos. Face ao messianismo, ele raciocina possuindo, exactamente como os 'Judeus', o evangelho de João".

Resta considerar a questão do divisionismo no seio dos judeus. Para VidalNaquet (1977, p.108), a explicação para as várias facções judaicas presentes na guerra de 66-73 d.C. radica na falta de força do nacionalismo judaico do séc. I d.C.. Tudo aquilo que configuraria o cimento do Judaísmo do pós-70 d.C. (o desenvolvimento da sinagoga, uma criação da diáspora; a multiplicação dos escribas sem estarem sob o controlo do Templo; etc.) não tinha ainda encontrado o seu lugar no seio das instituições antigas; e, aparentemente, não havia condições para a criação de novas instituições, ou de grupos sociais capazes de funcionar como um elemento unificador. Por tudo isto, o que se passa na Palestina é um resumo trágico da situação em que se encontra o Judaísmo no séc. I d.C.. Mais do que a derrota final dos judeus, o que é verdadeiramente notável é a amplitude da sua resistência!

\section{A revolta}

Convém agora apresentar os contornos genéricos da revolta judaica que despoletou a guerra de 66-73 d.C., culminando os movimentos de massas que surgiram desde inícios do séc. I d.C.. Para este conjunto de eventos, Josefo constitui a nossa principal testemunha.

Logo após a morte de Herodes, que durante o seu reinado afastara cruamente toda a oposição ao seu domínio, a agitação popular entra, como vimos, em crescendo. A Judeia está repleta de salteadores, há sinais muito inquietantes de generalização da anarquia e de carnificinas (até mais contra compatriotas judeus do que contra os romanos), vivemos no período dos chamados "reis efémeros". O apoio do imperador Nero, em 59-60 d.C., aos síriofenícios helenizados da Judeia (os 'gregos'), contra os 'habitantes sírios' de 
Jerusalém, ao tempo em que Félix era procurador (59-60 d.C.), avolumou consideravelmente o mal-estar.

Desde 60 d.C., a situação agrava-se pois Roma começa a nomear como procuradores da Judeia quadros de menor envergadura. Foi o caso de Alibino (6062 d.c.), que parece ter aceitado subornos dos bandidos judeus que aterrorizavam os que cooperassem com Roma, mas também o de Géssio Floro (64-66 d.C.), que manteve esta prática e que, quando judeus e residentes sírios de Cesareia entraram em conflito, tomou a decisão fatal de requisitar dinheiro ao tesouro do Templo para suprir as suas carências financeiras. Para muitos, as causas concretas da ruptura entre Roma e a Judeia acham-se na reacção a estas exacções de Floro, as quais motivaram uma explosão de violência em Jerusalém, com lutas de rua entre judeus e soldados romanos. A isto acresceu a rejeição dos sacrifícios em nome de César por parte dos ministros do culto judaicos, sob instigação do comandante do Templo (Eleazar), uma reacção que teve implicações políticas e, sobretudo, religiosas: Javé torna-se de novo no Deus de Israel; surgem novas moedas, de prata e não de bronze, com símbolos religiosos e legendas sugestivas (p.ex., sobre a "Liberdade de Sião", a "Redenção de Sião", "Jerusalém-a-Santa"); etc.

Sem conseguir restabelecer a ordem, Floro é obrigado a fugir da cidade, onde a guarnição romana é massacrada. Pede então auxílio a Caio Céstio Galo, legado imperial na Síria, que reúne à pressa um exército e marcha sobre os rebeldes, alcançando Jerusalém em finais de 66 d.C.. Espantado pela dimensão da revolta, Céstio Galo sofreu alguns revezes e acabou por retirar, mas a coluna romana foi duramente fustigada quando descia pela estreita passagem de BerthHoron, sofrendo 5.780 baixas (GOLDSWORTHY, 2007, p.373)! Nero seria então obrigado a enviar o seu melhor general, Vespasiano (com 57 anos de idade), para esmagar a insurreição judaica.

Entretanto, na Judeia começavam a grassar as lutas internas, com muita aristocracia rural e algumas cidades a mostrarem-se contrárias a uma guerra com Roma, opção que também não granjeava a simpatia de saduceus e de muitos fariseus (mais preocupados com a religião do que com a política). Como vimos, o rei Agripa II ainda tenta convencer os rebeldes a fazerem a paz, mas o aparecimento de um partido novo e radical (os zelotas), apoiado por apenas uma pequena parte da população da Palestina, como que tornou a guerra inevitável. Os cristãos, pelo seu lado, marcados pelo avolumar da tensão entre a sua Igreja e a ortodoxia judaica estabelecida, assim como pela execução de Tiago (irmão de Jesus) por ordem do Sumo-sacerdote, optaram por abandonar Jerusalém e rumar à Transjordânia (Armstrong, 2002, p.144-147).

Em síntese, era o culminar de um ciclo de inquietude no seio da sociedade judaica da Palestina. Muitas das revoltas destas décadas parecem ter tido uma 
Flávio Josefo e o cerco romano a Jotapata (67 d.C)

base camponesa, concentrando-se sobretudo em Jerusalém, em particular no Templo. É certo que não podemos ignorar a existência de algumas (mais raras) revoltas urbanas, como por exemplo as ocorridas sob Pôncio Pilatos, antes de 31 d.C., quando este procurador tentou introduzir em Jerusalém insígnias com a efígie imperial, ou construir um aqueduto a expensas do Tesouro do Templo. Mas o grosso da revolta era protagonizado pelos camponeses da Judeia, indiciando que, como comenta Josefo, toda a Judeia estava doente.

Paradoxalmente, a revolta do Verão de 66 d.C., em Jerusalém, foi, no seu início, sobretudo urbana, concentrando, por um lado, o rei Agripa II (mais os principais cidadãos, os chefes religiosos e os fariseus mais notáveis) na cidade alta, e, por outro, os sediciosos e os revolucionários na cidade baixa e no Templo. Para compreendermos a profundidade da explosão contestatária temos também de lembrar o massacre dos judeus levado a cabo, nesse mesmo ano, em Cesareia, em Citópolis, em Gadara e em Áscalon. Na verdade, a reacção judaica à notícia do massacre da capital da Judeia foi tremenda, ajudando a explicar a citada chacina da guarnição romana de Jerusalém. Seguiram-se mortes e incêndios diversos de Gadara até Gaza, passando por Áscalon e por Sebasta. Os confins desérticos da Idumeia, onde populações judaizadas e populações árabes eram vizinhas, também não estavam menos agitados.

O massacre da guarnição romana de Jerusalém foi impressionante. Nas primeiras horas da revolta, os soldados refugiaram-se nas torres da fortaleza da Cidade Santa, aí enfrentando uma verdadeira luta de classe. Seriam, porém, forçados a capitular, dando lugar a uma espécie de governo revolucionário provisório, chefiado pelo Sumo-sacerdote Haná, a quem coube preparar (parece que mal) Jerusalém para resistir à mais que certa resposta de Roma. Nesta altura, Eleazar e os zelotas impuseram-se ao povo e começaram a suceder-se as medidas económicas e sociais tomadas pelos revoltosos judaicos, um pouco à maneira das cidades gregas: destruição (pelos sicários, que também promoveram a abolição das dívidas) de arquivos, libertação de escravos, execução de gente rica, tiragem à sorte para o acesso a altos cargos, radicalização dos jovens contra os mais velhos, etc. (Vidal-Naquet, 1977, p.102-103).

Em Julho de 67 d.C., os samaritanos, em estado latente de revolta, viramse encurralados na sua montanha sagrada e foram massacrados pelas tropas do legado romano Sexto Vetuleno Cereal (J. BJ 3.7.307-315). Mais decisiva ainda seria a queda da Galileia, na sequência da tomada de Jotapata por Vespasiano, em Julho de 67 d.C.. Este acontecimento conduziria à entrada em Jerusalém, em finais de 67 d.C., de uma multidão de refugiados da Galileia sob o comando de João de Gischala (que fora um encarniçado rival de Josefo pelo controlo da Galileia), assim como dos chefes dos salteadores do mundo rural. Isto ajuda a explicar a intervenção massiva do grupo dos zelotas e os excessos e infâmias que, 
a partir de então, seriam praticados na capital religiosa da Judeia, como Josefo noticia no seu amplo e comovente relato do cerco de Jerusalém, em 70 d.C. (J. BJ 5 e 6).

Entrou-se então numa fase de verdadeira guerra civil judaica dentro de Jerusalém, com uma forte intervenção rural e com os zelotas no poder enfrentando o "povo" do Sumo-sacerdote Haná. Esta autêntica 'guerra de classes' foi durante algum tempo arbitrada por João de Gischala e o equilíbrio reinante acabou por conduzir ao apelo feito aos idumeus de Simão bar Giora pelos zelotas. Disso resultou a morte de Haná e a pilhagem da Cidade Santa pelos idumeus de Simão, gerando uma situação calamitosa que Josefo considerou como o prenúncio do fim de Jerusalém e do Estado judaico.

O cerco de Jerusalém terminaria com a vitória romana, o incêndio do Templo e a derrocada da Cidade Santa. O triunfo de Vespasiano e de Tito conduziria à ocupação permanente da Palestina. À conquista de Jerusalém seguirse-iam as tomadas de Heródio, de Maqueronte e a tristemente célebre captura, pelo legado Lúcio Flávio Silva, em 73 d.C., de Masada (onde a resistência judaica, que reunia muitos extremistas zelotas, optou pelo suicídio colectivo).

Como comenta Vidal-Naquet (1977, p.95-96), a guerra judaica de 66-73 d.C. consiste numa insurreição seguida de uma grande destruição; trata-se de um drama nacional que, segundo o mesmo autor, não deixa de lembrar os acontecimentos da Revolução Francesa ou os da Comuna de Paris, com os seus gritos de "liberdade ou morte!".

\section{A narrativa e o seu autor}

Como vimos, Flávio Josefo nasceu em 37 ou em inícios de 38 d.C. (no início do principado de Calígula), no seio de uma família sacerdotal. Descendia, por via materna, dos reis asmoneus. Aos 14 anos tornou-se "doutor da Lei" e, pouco mais tarde, completou o seu périplo por diferentes seitas judaicas e impôs a si mesmo um período de retiro no deserto.

Em 64 d.C., Josefo acompanhou a Roma um grupo de padres que foi detido pelo procurador Félix. Nessa aflição, tentou intervir junto do imperador Nero no sentido de obter a libertação dos seus companheiros. Na altura, descobriu com espanto que o mimo favorito do imperador era um judeu e que a esposa de Nero era, provavelmente, uma convertida! Graças a eles, Josefo obteria a libertação dos seus camaradas.

Nascido para ser rabino, as circunstâncias acabaram por fazer de Josefo um Reitor. Em 66 d.C., após a insurreição que expulsou os romanos de Jerusalém, ele era já o comandante-em-chefe da frente Norte, na Galileia - a mais exposta ao contra-ataque romano. No final do cerco de Jotapata, na Galileia, Josefo viu-se refugiado numa gruta juntamente com 40 companheiros. Viveu então um dilema 
Flávio Josefo e o cerco romano a Jotapata (67 d.C)

cruel: aceitar a fuga para o lado romano ou optar pelo suicídio, como pretendiam os seus correligionários? Josefo começa por propor uma rendição honrosa, mas os companheiros não aceitam qualquer capitulação e dão-lhe a escolher entre a morte dos bravos e a dos traidores. Contrário ao suicídio, Josefo propõe uma alternativa: a degolação recíproca, após tiragem à sorte (o n.o 2 mataria o n. 1 , o n. -3 executaria o n.o 2 e assim sucessivamente). Esta opção foi aprovada, mas Josefo teve a habilidade suficiente para ficar para o fim, circunstância providencial e que ele aproveitou, convencendo o seu único companheiro sobrevivo a salvarem-se os dois...

Josefo passou então para o acampamento romano, tendo recebido inúmeros favores da parte de Vespasiano e de seu filho Tito. No cerco de Jerusalém, Tito usaria Josefo para tentar convencer os habitantes da cidade a render-se. O procedimento não resultou, mas revela a integração de Josefo no meio romano, o que ajuda também a explicar o seu casamento com uma jovem cativa de Cesareia, ao que parece por indicação de Vespasiano (Vidal-Naquet, 1977, p.66).

Certo é que Josefo passou a viver em Roma e foi na cidade eterna que escreveu a sua obra, durante os principados de Vespasiano (69-79 d.C.), de Tito (79-81 d.C.) e de Domiciano (81-96 d.C.), concluindo em 93 d.C. as Antiguidades Judaicas e, em 93-96 d.C., o Contra Apião. Nas suas narrativas, Josefo surge como um mediador entre judeus e romanos, tentando justificar a guerra praticada pelos primeiros. Em A Guerra dos Judeus, oferece aos gregos e aos romanos um "memorial dos altos feitos" (Vidal-Naquet, 1977, p. 12). O seu texto, apesar de grego, contém a versão romana dos acontecimentos que pontuaram de sangue a Guerra Judaica de 66-73 d.C.: "Trata-se da guerra dos romanos contra os judeus, e não da guerra entre os judeus e os romanos tal qual ela teria podido ser escrita por um observador parta" (Vidal-Naquet, 1977, p.13). As suas fontes são romanas, ou próromanas, e a sua versão dos trágicos acontecimentos constituiu a versão oficial romana dos mesmos, tendo sido caucionada e rubricada por Tito, que ordenou a respectiva publicação. Ao que parece, também o rei Agripa II, o rei-cliente judaico que acompanhara Vespasiano e Tito, escreveu (segundo diz Josefo) 62 cartas atestando a veracidade do relato do escritor! Para este, Deus estava com Roma, a herdeira do mundo antigo e de quem os próprios atenienses se haviam tornado escravos...

Josefo é um autor importantíssimo para o conhecimento da máquina militar romana e, nesse sentido, ele recorda Políbio (203-120 a.C.) na sua tentativa comum de compreender o exército que os havia vencido: "Eu dei estas explicações detalhadas não tanto porque o meu desejo consista em exaltar os romanos, mas mais para consolar os povos que foram submetidos por eles e para fazer reflectir aqueles que poderão ter a tentação de se sublevar" (J. BJ 3.5.108). 
Entretanto, Josefo, apesar de advogar juntos dos judeus a causa dos seus senhores romanos, patenteia um grande orgulho em ser judeu, salientando nas suas narrativas a grande firmeza de alma deste povo e a sua extraordinária capacidade para suportar a sedição, a fome, a sede, a guerra e as maiores calamidades. Este quadro surge bastante enfatizado na medida em que, perante a Roma imperial, Josefo apresenta Jerusalém e a Judeia "num isolamento esplêndido e aterrador". E é esta função de mediação desempenhada por Josefo que justifica o comentário-síntese de Pierre Vidal-Naquet: "Existe Roma e existem os judeus: entre os dois, existe Josefo" (Vidal-Naquet, 1977, p.16).

Sabemos que A Guerra dos Judeus foi publicada entre 76 e 79 d.C., ou seja, escassos anos após o termo do conflito. No day after deste confronto, Josefo escreveu, em aramaico, a sua obra, que enviou "aos povos estrangeiros [bárbaros] do interior da Ásia” (J. BJ 1.3). Como explica Vidal-Naquet (1977, p.18), "é para esses não-gregos, a fim de lhes evitar os padecimentos que os judeus da Palestina tinham sofrido ao resistir ao Império Romano, para os judeus de Babilónia, para os de Adiabene, na Alta Mesopotâmia, cujos reis se tinham convertido ao Judaísmo, para os Árabes, para os habitantes do Império parta, que Josefo tinha, logo no dia seguinte à guerra, escrito a sua obra - em aramaico", que confessa tratar-se da sua língua materna.

A versão inicial da obra de Josefo perdeu-se para sempre. Todas as versões de que dispomos derivam do texto grego; no início de $A$ Guerra dos Judeus (J. BJ 1.3), Josefo explica, aliás, que traduz para grego a obra que compôs originalmente em aramaico (um aspecto que confirma a ideia da helenização da Palestina). Segundo alguns autores, a retórica de Josefo remonta a Eurípides, do mesmo modo que talvez seja possível encontrar um paralelo sugestivo entre os títulos e os inícios de A Guerra dos Judeus, por um lado, e da História da Guerra do Peloponeso, de Tucídides, por outro (Vidal-Naquet, 1977, p.15 e 20).

Usando fontes escritas e orais, romanas, aramaicas e hebraicas, Josefo compôs portanto uma narrativa de forte sentido pedagógico, exemplar, e, além disso, ponderada. Na obra que mais nos interessa, $A$ Guerra dos Judeus, só os moderados têm realmente voz: sobretudo Josefo, Agripa II, o Sumo-sacerdote Haná, os chefes romanos (em especial, Tito, por quem o escritor nutre um afecto particular). As excepções (como Eleazar em Masada-73 d.C., ou Simão em Jerusalém) são raras.

Podemos questionar o grau de integração de Josefo no mundo romano, após a sua captura em Jotapata. Não é fácil responder a esta pergunta, pois desconhecemos se Josefo (cujo nome romano deverá ter sido Titus Flavius Josephus $^{4}$ ) fez carreira no Império e sob que forma. De Vespasiano, Josefo recebeu terras, uma casa e uma pensão. Suetónio menciona-o como um "nobre cativo" que prediz o império para Vespasiano. Segundo Vidal-Naquet (1977, p.28), 
Flávio Josefo e o cerco romano a Jotapata (67 d.C)

talvez a sua pensão equivalesse à de 100.000 sestércios que Vespasiano atribuiu aos Reitores latinos e gregos pela primeira vez. Se esta hipótese for verdadeira, então o tratamento dispensado a Flávio Josefo equivaleria à condição de um alto funcionário.

O percurso e as opções de Josefo suscitaram uma apreciação divergente. Um cristão como Eusébio de Cesareia elogiou-o, considerando-o "de longe o mais célebre dos judeus do seu tempo", aos olhos de romanos e de não-romanos, o que lhe valeria uma estátua em Roma e a honra da presença das suas obras mais sérias nas grandes bibliotecas coevas. Já o israelita Z. Yavetz vê Josefo como simples membro de um séquito inferior do imperador romano, ao lado de médicos, de mágicos, de filósofos e de bufões, nunca tendo recebido o título oficial de "amicus Caesaris" (Vidal-Naquet, 1977, p.28).

Tito Flávio Josefo permaneceu perto de três décadas instalado em Roma, na condição de homem livre, aí se tornando "o historiador da guerra da Judeia, o historiador do povo judeu face a Roma (em Antiguidades), o defensor da lei judaica e da antiguidade judaica face aos Alexandrinos (em Contra Apião), o historiador de si mesmo (na Autobiografia)" (Vidal-Naquet, 1977, p.29). É uma felicidade tremenda, que devemos relacionar com o triunfo do Cristianismo no mundo romano, podermos dispor hoje da obra completa deste notável escritor, a quem S. Jerónimo chamou "o Tito Lívio grego" ${ }^{5}$ e que o Ocidente latino leu, pelo menos até à Contra-Reforma, quase como um texto sagrado. $O$ ponto alfa da sua narrativa da Guerra Judaica situa-se em 170 a.C., por altura dos acontecimentos que agitaram a Judeia na época de Antíoco IV Epifânio; o ponto ómega prolongase para além da captura de Masada (em 73 d.C.), na direcção do Egipto e da Cirenaica, mas Josefo tinha planos para mais, pois sabemos que em 93 d.C. o infatigável historiador tinha intenção de escrever "de novo, em resumo, a guerra e aquilo que nos aconteceu até ao presente dia" (J. AJ 22.267).

Teodoro Reinach considerou Flávio Josefo como "nem um grande espírito, nem um grande carácter, mas sim um composto singular de patriotismo judaico, de cultura helénica e de vaidade ${ }^{\prime 6}$. Historiador brilhante, Judeu controverso (traidor, sem dúvida, no contexto político-militar do seu tempo), a ele devemos uma das mais minuciosas descrições da fabulosa máquina militar romana em acção no séc. I d.C., e nós trataremos agora de a aproveitar o melhor possível, centrando-nos no cerco de Jotapata por Vespasiano, em 67 d.C..

\section{O cerco romano a Jotapata ${ }^{7}$}

O relato de Flávio Josefo sobre os acontecimentos militares de 67 d.C. começa por uma breve referência aos raides de Plácido (chefe militar romano) na Galileia e seu subsequente avanço para Jotapata ${ }^{8}$, considerada a chave-militar de toda a província. Tendo tomado conhecimento do ataque de Plácido, os 
habitantes de Jotapata decidiram aguardá-lo fora da cidade. Daí resultou um ataque bem-sucedido aos romanos, com os judeus a tirarem partido do seu equipamento mais ligeiro e a combaterem de longe a infantaria pesada, evitando o corpo-o-corpo (J. BJ 3.6.112-113).

Josefo descreve depois a ordem de marcha de Vespasiano no seu avanço entre Ptolemaida (Acre) e Jotapata ${ }^{9}$. Na sequência desta marcha, Vespasiano alcança as fronteiras de Galileia. Os seus preparativos para cercar as fortalezas geram um grande terror entre os judeus e daí resulta que Josefo se veja subitamente abandonado por compatriotas seus, restando-lhe um pequeno número de soldados fiéis, com os quais se refugia em Tiberíades (J. BJ 3.6.127-131).

No capítulo seguinte (Livro III, cap. 7), Josefo recorda a tomada de Gabara (na Galileia, c. 25 km a leste de Ptolemaida) e a matança e incêndio então perpetrados pelos soldados de Vespasiano, exprimindo o seu ódio pela nação judaica e o seu desejo de vingar o crime por esta anteriormente cometido contra o legado Céstio Galo. Perante a progressão adversária, Josefo, alarmado, decide enviar um relatório a Jerusalém, solicitando que se opte entre a rendição ou o envio de um reforço capaz (J. BJ 3.7.132-140).

Vespasiano parece ansioso por atacar Jotapata, uma excelente base dos adversários. Para tanto, envia um destacamento de infantaria e de cavalaria com a missão de aplanar os acessos, visto tratar-se de um caminho de montanha, muito pedregoso. Em quatro dias, "abrem ao exército uma larga estrada" (J. BJ 3.7.141-142). No dia seguinte (8 de Junho), Vespasiano alcança Jotapata (aonde Josefo também já chegou) e enceta os preparativos do cerco. Vespasiano parece contente por saber da presença de Josefo, pois era o inimigo de quem mais queria apoderar-se, por ser "o mais inteligente" deles (J. BJ 3.7.144)...

Plácido e o decurião Aebútio bloqueiam então a cidade de modo a impedir Josefo de fugir. O acampamento romano é instalado, para pavor dos judeus que assistem à distância. Os romanos formam três linhas de cerco (duas de infantaria, reforçadas por uma exterior, de cavalaria) e cortam todas as saídas aos sitiados. Porém, parecem esquecer-se de que a ausência de um caminho de fuga galvaniza quase sempre a coragem dos de dentro (J. BJ 3.7.144-149).

Dá-se depois o primeiro ataque romano contra a posição exterior dos judeus (que aguardavam o inimigo em frente às muralhas). Josefo consegue repelir o ataque romano (arqueiros, fundibulários e tropa de infantaria comandada por Vespasiano). O combate foi duro e duraria até à noite, provocando muitas baixas: 13 mortos e grande número de feridos, do lado romano; 17 mortos e cerca de 600 feridos, entre os judeus (J. BJ 3.7.150-154).

Nos dias seguintes têm lugar outros ataques romanos e diversos contraataques judeus, sob a forma de surtidas fulgurantes. Os soldados romanos começam a sentir alguma vergonha por não conseguirem chegar rapidamente à 
Flávio Josefo e o cerco romano a Jotapata (67 d.C)

vitória. Porém, a verdade é que a fortaleza de Jotapata era quase inexpugnável: dispunha de uma posição natural muito forte e só do seu lado norte era mais acessível, o que levara Josefo, quando fortificou a cidade, a incluir esse troço dentro da própria muralha. Além disso, a cidade era quase invisível, pois estava rodeada de montanhas (J. BJ 3.7.155-160).

Vespasiano reúne o seu conselho de guerra, onde se decide a construção de um terraço ou rampa de assalto, em terra, do lado norte. Os romanos vão em busca de terra e de pedras nas montanhas vizinhas. A isto reagem os de dentro fazendo tiro a partir das muralhas, o que obriga os romanos a estender caniços sobre as paliçadas, para conseguirem construir o pontão. Mas os judeus não desarmam e lançam pedregulhos sobre as cortinas de protecção dos romanos e todo o género de projécteis, com grande algazarra (J. BJ 3.7.161-165).

Josefo explica depois como Vespasiano instalou de forma concêntrica, à volta daquela parte do muro, 160 engenhos de tiro que transportara consigo: catapultas que projectavam dardos com um som estridente; e balistas que arremessavam pedras com um talento (c.26 kg) de peso. Os romanos lançavam também dardos inflamáveis e um chuveiro de flechas, batendo não só a muralha mas todo o espaço interior de Jotapata. Uma multidão de arqueiros árabes e todos os lançadores de dardos e fundibulários actuava em simultâneo com os engenhos. Quanto à reacção judaica, consistia sobretudo em organizar surtidas que visavam arrancar as protecções dos construtores da rampa de assalto, atacar os respectivos operários, destruir a rampa e incendiar as paliçadas. Por isso, Vespasiano decidiu unir os telheiros de protecção do terraço de assalto de modo a dificultar os ataques, conseguindo conter melhor as incursões judaicas (J. BJ 3.7.166-170).

Entretanto, a rampa tinha já a altura da muralha, o que obrigou os judeus a sobrelevar o muro, protegidos por uma paliçada fixada à muralha e revestida por peles de bois frescas e húmidas. Um regime de trabalho intensivo, de dia e de noite, permitiu aos judeus elevar o muro uns 20 côvados (c.13,20 m), incorporando torres e ameias, o que gerou um grande desalento entre os romanos. Ao mesmo tempo, os sitiados insistiam nas surtidas, recorrendo a todas as manhas do banditismo e concretizando o maior número possível de pilhagens e de incêndios (J. BJ 3.7.171-177).

Perante isto, Vespasiano optou por conter a resposta armada e por bloquear a cidade, na esperança de a render pela fome (ou pela sede): esgotados pela privação dos alimentos, os judeus não seriam capazes de combater a sério. De facto, dentro de Jotapata, se os víveres não escasseavam (a não ser o sal), havia por outro lado pouca água já que as cisternas eram apenas alimentadas pela chuva e estava-se a entrar no Verão. Tal facto forçou Josefo a organizar um racionamento rigoroso, causador de grandes padecimentos. Do alto das colinas 
que rodeavam a cidade, os romanos podiam até observar os ajuntamentos dos sitiados para distribuição de água, aproveitando para fazer tiro de catapulta sobre essas pequenas multidões. Compreendendo que o adversário apostava no esgotamento das cisternas, Josefo recorreu a um estratagema: um grande número de habitantes surgiu nas muralhas com as vestes ensopadas, para dar aos romanos a ilusão de que a água abundava na cidade! Foi o estupor entre os romanos, que se sentiram desencorajados. Aí, Vespasiano decidiu voltar ao ataque, que era aliás, segundo Josefo, o que os judeus mais queriam para poderem morrer combatendo, com glória, e não ressequidos pela fome ou pela sede (J. BJ 3.7.178-189).

Neste ponto, o escritor introduz na sua narrativa uma petite histoire muito saborosa: a partir da cidade havia um caminho secreto que permitia aceder à ravina do lado ocidental, a qual era de tal modo inacessível que os postos de guarda romanos a negligenciavam. Ora, Josefo conseguia fazer passar por aí os seus 'correios', que levavam e traziam do exterior cartas e abastecimentos preciosos. Quando exploravam este caminho improvável, os mensageiros judaicos tinham instruções para avançarem "o mais possível a quatro patas" sempre que passassem perto das sentinelas romanas. Inclusivamente, levavam peles de animais pelas costas, de maneira a serem tidos por cães, caso fossem avistados de noite! Todavia, os Romanos acabaram por descobrir o estratagema e a ravina começou a ser guardada (J. BJ 3.7.190-192).

$\mathrm{O}$ assédio complica-se e Josefo decide preparar com os dirigentes judaicos a sua fuga. Porém, a população apercebe-se e implora-lhe que fique e que resista com eles até ao fim, pois Josefo era como um comandante de um navio, sem o qual toda a esperança de resistir se esvairia. O líder argumenta que lhes poderia ser mais útil fora do que dentro da cidade, pois reuniria os Galileus e abriria uma segunda frente; e alega que os soldados de Vespasiano queriam sobretudo era capturá-lo, pelo que, se ele partisse, os romanos abandonariam o cerco. Tudo em vão: os sitiados pressionam Josefo para que fique pois acreditam que, se ele ficar, nada de horrível poderá acontecer-lhes. Assim, Josefo regressa aos combates diários, que se traduzem em surtidas judaicas constantes para tentar incendiar as protecções da rampa de assalto dos romanos (J. BJ 3.7.193-206).

Como os romanos tinham dificuldade em responder a tais ataques (devido ao seu equipamento ser demasiado pesado para perseguir os sitiados que fugiam para dentro da fortaleza), Vespasiano ordena à infantaria pesada que evite o combate com aquela gente desesperada e aposta sobretudo nos arqueiros árabes e nos fundibulários e lançadores de pedra sírios para repelir os judeus; ao mesmo tempo, os numerosos engenhos de tiro não param de trabalhar. Em resposta, quando se acham aquém da zona de impacto desses engenhos de longo alcance, os judeus forçam o corpo-a-corpo, revezando as suas tropas mais fatigadas 
Flávio Josefo e o cerco romano a Jotapata (67 d.C)

através de um sistema de roulement coordenado a partir de dentro (J. BJ 3.7.207212).

Nesta altura, Vespasiano (que já estava a ficar com a impressão de ser ele o sitiado) decide pôr em acção um aríete. A grande eficácia e a potência deste dispositivo de vaivém, movimentado por uma grande quantidade de servidores e equipado com uma cabeça de ferro, merece a Josefo o seguinte comentário: "Não existe torre suficientemente sólida ou muro suficientemente espesso que possam, mesmo que aguentem o primeiro choque, resistir a golpes repetidos" (J. BJ 3.7.217). Ao mesmo tempo, os servidores das catapultas e dos outros engenhos de tiro aproximam as suas máquinas o suficiente para poderem atingir os judeus que, a partir das ameias, tentam impedir a aproximação do aríete. 0 mesmo fazem os arqueiros e os fundibulários ao serviço de Vespasiano. Assim, os judeus não ousam assomar aos muros e os romanos conseguem colocar o aríete em posição, cobrindo-se com caniçadas ligadas umas às outras e revestidas de peles (para sua protecção e da própria máquina). Ao primeiro golpe do aríete, o muro estremeceu e ouviu-se um clamor formidável vindo de dentro da cidade, "como se ela já tivesse sido capturada" (J. BJ 3.7.221)! (J. BJ 3.7.217-221).

Coube então a Josefo recorrer a um dispositivo para neutralizar o aríete: alguns sacos de palha pendurados nos muros e descidos pelo meio de cordas foram interpostos entre a cabeça da máquina e a zona do muro que estava a ser batida, de modo a amortecer os golpes. Mas aí os soldados de Vespasiano deitaram mão a grandes varas com ferros de foice nas pontas, com as quais cortavam as cordas dos sacos almofadados... Josefo recorre ao fogo, preparado através de uma mistura de madeira seca, de betume, de pez e de enxofre: um incêndio começa então a grassar por todo o lado, consumindo os trabalhos dos romanos (J. BJ 3.7.222-228).

A narrativa de Josefo abre aqui um parêntese para enaltecer o heroísmo de Eleazar, um nativo de Gaba que atacou sozinho o aríete, e de dois irmãos galileus que se excederam em bravura (J. BJ 3.7.229-233).

Nesta fase da operação, judeus de tochas na mão circulam pelo exterior da muralha e procuram aniquilar abrigos e máquinas da 5. a e da 10. a legiões. Quanto aos romanos, tentam proteger tudo com terra (engenhos e materiais em madeira) e recolocam o aríete no ponto mais frágil do muro, ou seja, onde ele já tinha operado. É neste momento que Vespasiano é ferido num pé por uma flecha lançada do muro: soa o alarme entre os sitiadores, mas trata-se de uma ferida superficial (J. BJ 3.7.234-239).

Podemos depois desfrutar das páginas mais emocionantes sobre o cerco de Jotapata. Massacrados pelos engenhos romanos, os Judeus vão caindo, mas resistem sempre. Muitos tombam dos muros e agonizam lá em baixo. Nessa noite, o fogo acaba por tornar os judeus num alvo iluminado e eles caem com os 
golpes de escorpiões e de balistas que nem chegam a ver. Os projécteis das catapultas romanas matam vários de uma assentada, enquanto as pedras das balistas desmontam ameias e cunhais. Um tiro de balista chega mesmo a arrancar a cabeça a um homem que está junto de Josefo, lançando o respectivo crânio a três estádios de distância. Uma mãe grávida leva com um míssil no ventre, tendo o bebé sido projectado cerca de 100 metros! As máquinas romanas emitem silvos e ruídos arrepiantes. Os corpos dos sitiados caem do alto, uns sobre os outros, e a acumulação de cadáveres é tal que facilita o acesso à muralha por parte dos soldados romanos. Enquanto isso, a montanha em volta de Jotapata ecoa os sons dramáticos do combate, tornando aquela numa noite memorável. O muro acaba por ceder e os Judeus, sem mais opção, põem os seus próprios corpos a colmatar as brechas, enquanto os Romanos se preparam para adossar as escadas de assalto à muralha (J. BJ 3.7.240-252).

Ao nascer do sol, os romanos organizam um ataque em várias linhas: i) os cavaleiros mais bravos desmontam e formam três colunas de assalto frente aos troços derrubados do muro; estão couraçados e munidos de lança, prontos a penetrar logo após a colocação das escadas de assalto; ii) atrás deles, posiciona-se a infantaria de elite; iii) ao resto da cavalaria caberá cobrir a ligação à montanha para evitar as fugas; iv) atrás deste cordão de cavalaria estão os arqueiros, os fundibulários e os engenhos de tiro. Em simultâneo, Vespasiano manda preparar o encosto de escadas às partes intactas da muralha para forçar os judeus a dividir as suas forças (J. BJ 3.7.253-257).

A esta ofensiva respondeu Josefo do seguinte modo: i) colocou os combatentes mais fatigados (ou mais idosos) na parte boa da muralha, onde a defesa era mais fácil; ii) nas brechas abertas pelos romanos posicionou os homens mais fortes, em grupos de seis tirados à sorte (incluindo ele próprio); iii) depois, deu ordem a todos para taparem os ouvidos no momento do grito de guerra romano; iv) mandou também que, contra os projécteis, apoiassem um joelho em terra, os homens escondidos atrás dos escudos, um pouco recuados, enquanto os adversários esvaziavam as aljavas; v) quando os romanos tivessem as escadas encostadas à muralha, os judeus deveriam avançar, com a ajuda dos seus próprios engenhos, e vingar a sua gente; vi) as mulheres foram mandadas recolher para não desmoralizarem os outros com os seus gritos de terror (J. BJ 3.7.258-263).

As trombetas romanas dão então o sinal de ataque. Sucede-se um grito de guerra terrível, completado por disparos comandados por um sinal. Os romanos colocam as plataformas de assalto em posição, mas logo a seguir os judeus lançam-se ao ataque e impedem-nos de as utilizar. Inicia-se um corpo-a-corpo letal, em que os romanos levam vantagem por conseguirem organizar-se de modo a que tropas frescas substituam rapidamente as que se encontram esgotadas, ou 
Flávio Josefo e o cerco romano a Jotapata (67 d.C)

que são repelidas; além disso, estão bem protegidos na cabeça e no tronco e actuam em bloco cerrado (J. BJ 3.7.265-269).

Nesta aflição, Josefo manda derramar óleo a ferver sobre a 'tartaruga' romana que avança para a muralha. $\mathrm{O}$ ardil resultou, causando uma dor imensa e a desorganização da tropa de progressão romana (o óleo aquecia depressa e arrefecia devagar, por causa da gordura). Os romanos vêem-se aprisionados nas suas lorigas e capacetes, não conseguindo escapar à queimadura: saltam e contorcem-se de dor, caindo nas rampas de assalto e chocando com os camaradas que chegam para os socorrer. Os judeus aproveitam a situação e começam a matá-los por trás (J. BJ 3.7.271-275).

Logo a seguir, Josefo ordena o derrame de feno-grego (uma planta leguminosa) fervido sobre as tábuas dos passadiços de assalto: alguns romanos desequilibram-se, caem de costas e são espezinhados, enquanto outros são projectados sobre a rampa, onde os dardos judaicos os trespassam. Mais libertos do corpo-a-corpo, os judeus aproveitam para fazer tiro sobre os adversários. Ao cair da tarde, Vespasiano recolhe os seus homens. Muitos, furiosos, insistem em continuar a combater. Mas as baixas já são significativas; os defensores de Jotapata perdem só seis homens, mas mais de 300 feridos são conduzidos para o interior da cidade. Tudo isto aconteceu no dia 8 de Julho (J. BJ 3.7.277-282).

Vespasiano decide então elevar o terraço de assalto e manda construir três torres de 50 pés (c.15 m) forradas de ferro (para serem mais resistentes ao fogo), as quais instala na própria rampa, recheadas de atiradores de vário tipo (dardeiros, arqueiros, fundibulários) e até com engenhos ligeiros lá dentro. 0 novo dispositivo é eficaz: os atacantes estão agora demasiado altos para os judeus os conseguirem atingir e os sitiados nem sequer os avistam bem! Assim, os homens de Josefo trocam a defesa das ameias por novas surtidas. As baixas aumentam dia após dia (J. BJ 3.7.284-288).

Neste ponto, Josefo explica que Trajano (o comandante da 10. legião) foi então enviado para tomar a cidade rebelde de Yafa (perto de Nazaré), à frente de um destacamento de 1.000 cavaleiros e 2.000 infantes. Tito acabaria por secundar esta bem sucedida operação, consumada no dia 13 de Julho. Josefo estima que terão morrido umas 15.000 pessoas (J. BJ 3.7.289-306).

Em Jotapata, ao 47. dia de cerco, a rampa de assalto ultrapassa já a altura da muralha. Um desertor informa então os romanos de que a melhor hora para atacarem é na última vigia ${ }^{10}$, pois devido à intensidade do sono as sentinelas têm tendência para adormecer. O mesmo informador avisa também os romanos de que os de dentro estão esgotados, sendo poucos aqueles que se acham em condições de lutar. Vespasiano desconfia, pois os judeus costumavam ser muito leais entre si (e até havia casos de torturados que não falavam, nem no momento 
da crucificação); ainda assim, decide seguir a pista e preparar o ataque (J. BJ 3.7.316-322).

À hora prevista, os romanos avançam para a estocada final com Tito e o tribuno Sabino na frente, acompanhados por alguns soldados da 5. a e da 10. legiões. Degolam as sentinelas que dormem, enquanto, mais atrás, Plácido e o tribuno Sexto Calvário fazem entrar as suas tropas. Os sitiados dormem e um nevoeiro intenso também ajuda os assaltantes. Os judeus são apanhados de surpresa. Dá-se uma matança brutal na descida da cidadela, com os defensores a serem esmagados nas ruelas e a escorregar pela colina. A carnificina é de tal ordem que os próprios soldados de elite de Josefo se juntam num extremo da praça para se matarem uns aos outros antes de serem apanhados. Alguns judeus refugiam-se numa torre, a norte, mas também acabam degolados. Entre os romanos regista-se apenas a baixa do centurião António, enganado por um judeu refugiado numa gruta. A matança prolonga-se pelos dias seguintes, em todos os esconderijos, subterrâneos e cavernas. Mais uma vez, só as mulheres e as crianças são poupadas. No total, Josefo fala em 40.000 mortos e em 1.200 prisioneiros. Conquistada a praça, Vespasiano manda arrasar a cidade e incendiar as respectivas fortificações. Para a história, fica a data da captura de Jotapata: 20 de Julho do ano 67 da era de Cristo (J. BJ 3.7.323-339).

No capítulo seguinte (cap. 8 do Livro III), Flávio Josefo relata ainda a busca de Josefo pelos romanos. Encontrado numa gruta ligada a uma cisterna funda, é convidado a sair, com garantia de salvaguarda da sua vida. Mas Josefo vacila e só o envio de um terceiro emissário (o tribuno Nicamor, seu amigo) o leva a admitir arriscar, num momento em que os soldados romanos ameaçavam já pôr fogo à caverna. Josefo lembra-se então dos sonhos em que Deus lhe anunciou o sofrimento dos judeus e os destinos futuros dos imperadores romanos. Logo a ele, que "era intérprete dos sonhos e hábil a decifrar as revelações ambíguas da divindade" (J. BJ 3.8.352). Tomado por uma inspiração profética, Josefo decide render-se para poder anunciar o futuro (como profeta e servidor de Deus, e não como traidor). Mas os seus 40 companheiros de gruta não estão de acordo e ameaçam-no de morte. Foi aí que Josefo engendrou o estratagema de organizar um suicídio colectivo por degolação, tendo o cuidado de se deixar ficar para o final de modo a conseguir salvar-se (J. BJ 3.8.340-391)...

Nicamor conduz finalmente Josefo a Vespasiano. Uma grande multidão de romanos acorre para observar o líder judeu. Tito, impressionado com a determinação de Josefo e com a sua juventude, pressiona o pai para conseguir a sua graça. Mas Vespasiano sujeita Josefo a uma guarda apertada e faz tenção de o enviar a Nero. Então, Josefo pede para falar a Vespasiano em particular (só na presença de Tito e de mais dois amigos deste). Segue-se o discurso em que Josefo se apresenta como profeta e em que profetiza mesmo a subida ao trono imperial 
Flávio Josefo e o cerco romano a Jotapata (67 d.C)

por parte de Vespasiano e, depois, por Tito ${ }^{11}$. Perante isto, Vespasiano hesita, desconfiado. Mas a verdade - explica o escritor - é que o general tinha as suas ambições imperiais e pôde confirmar (junto de prisioneiros judaicos) que Josefo já havia previsto a capitulação de Jotapata ao 47. dia, bem como a sua própria captura! Sendo assim, Vespasiano começa a acreditar no seu prisioneiro mais ilustre. Mantém Josefo bem guardado, mas, sob a influência de Tito, dá-Ihe boas prendas e trata-o muito bem (J. BJ 3.8.392-408).

Logo no início do capítulo 9 deste Livro III de A Guerra dos Judeus, Flávio Josefo remata a sua narrativa do cerco de Jotapata. Para explicar que, a 23 de Julho de 67 d.C., Vespasiano deixou Jotapata, rumo a Ptolemaida e, depois, a Cesareia, onde os romanos foram bem recebidos (J. BJ 3.8.409-410).

Termina aqui um dos principais episódios da Guerra Judaica de 66-73 d.C.. Em breve o cenário da narrativa se deslocará para Jerusalém, onde, no Verão de 70 d.C., decorrerá um cerco sanguinário que arrasará a Cidade Santa e o seu precioso Templo. Josefo também lá estará, mas agora do outro lado da trincheira, junto ao seu amigo Tito. Vespasiano já será, então, imperador. E Josefo chamarse-á agora, et pour cause, Tito Flávio Josefo...

\section{Documentação}

FLAVIUS JOSEPHE. La Guerre des Juifs. Traduit du grec par Pierre Savinel. Paris : Les Éditions du Minuit, 1977.

\section{Bibliografia}

ARMSTRONG, Karen. Jerusalém. Uma Cidade, Três Religiões. Ttrad. port. de Eduarda Correia. Lisboa: Temas e Debates, 2002).

GOLDSWORTHY, Adrian. Generais Romanos. Os homens que construíram o Império romano. Trad. port. de Carlos Fabião. Lisboa: A Esfera dos Livros, 2007.

VIDAL-NAQUET, Pierre. "Du bon usage de la trahison", in Flavius Josèphe, La Guerre des Juifs, traduit du grec par Pierre Savinel, Paris : Les Éditions du Minuit, 1977.

\footnotetext{
Notas

${ }^{1}$ Para a contextualização que aqui apresentamos, usaremos sobretudo Pierre Vidal-Naquet (1977), Karen Armstrong (2002) e Adrian Goldsworthy (2007).

${ }^{2}$ Herodes matou a sua esposa Mariana e três dos seus filhos, por conspirarem contra ele. Aos outros três filhos (Arquelau, Filipe e Antipas), nunca concedeu poderes e, quando morreu, deixou dois testamentos. O destino do reino ficou por isso nas mãos de Augusto, que chamou a Roma os três pretendentes, tendo o Senado optado por nomear Arquelau como etnarca da Judeia, e Antipas e Filipe como tetrarcas da Galileia, da Pereia e das outras regiões do Norte. As políticas impiedosas de Arquelau acabariam por levar à sua deposição e desterro, em 6 d.C.. A partir daí, a Judeia foi governada por prefeitos romanos, tendo Cesareia por capital. Cf. Armstrong (2002, p.137-139).

${ }^{3}$ Utilizaremos neste trabalho a edição francesa de $A$ Guerra dos Judeus referida na nota 1. 
4 Segundo o princípio dos tria nomina romanos, o praenomen e o nomen eram normalmente os nomes dos imperadores no poder no momento da atribuição da cidadania, enquanto o cognomen recordava o patronímico do beneficiário. Recorde-se que Josefo recebeu a liberdade das mãos do imperador Vespasiano (Titus Flavius Vespasianus). ${ }^{5}$ Citado por Vidal-Naquet (1977, p.30).

${ }^{6}$ Citado por Vidal Naquet $(1977$, p.33).

${ }^{7}$ Cf. J. BJ 3.6-8.110-408.

8 Jotapata: hoje Yodfat (a meio-caminho entre S. João de Acre e Tiberíades).

${ }^{9}$ Segundo Vidal-Naquet (1977, p.315), o exército de Vespasiano, que incluía três legiões com artilharia, cavalaria, infantaria e trem de apoio, devia formar uma coluna com mais de $15 \mathrm{~km}$ de extensão, para a qual é estimável um tempo de escoamento de mais de três horas.

${ }^{10}$ Julgo que equivalerá, aproximadamente, ao período entre as $4 \mathrm{~h}$ e as $7 \mathrm{~h}$ da manhã.

${ }^{11}$ A predição de Josefo é mencionada por Suetónio (Suet. Ves. 5), que escreve no final do séc. I - início do séc. II d.C.. 